Article

\title{
Ovarian Transcriptomic Analysis Reveals Differential Expression Genes Associated with Cell Death Process after Selection for Ovulation Rate in Rabbits
}

\author{
Marta Serna-García ${ }^{1,2}$, Rosa Peiró ${ }^{3}$, Eva Serna ${ }^{4, *}$ and María Antonia Santacreu ${ }^{1, *}$ \\ 1 Instituto de Ciencia y Tecnología Animal, Universitat Politècnica de València, 46022 Valencia, Spain; \\ garserma@hotmail.com \\ 2 Faculty of Agricultural and Veterinary Sciences, São Paulo State University, FCAV/UNESP, \\ Jaboticabal 14884-900, São Paulo, Brazil \\ 3 Instituto de Conservación y Mejora de la Agrodiversidad Valenciana, Universitat Politècnica de València, \\ 46022 Valencia, Spain; ropeibar@btc.upv.es \\ 4 Department of Physiology, Faculty of Medicine, University of Valencia, 46010 Valencia, Spain \\ * Correspondence: eva.serna@uv.es (E.S.); msantacr@dca.upv.es (M.A.S.); \\ Tel.: +34-963864100 (ext. 83171) (E.S.); +34-963879436 (M.A.S.)
}

Received: 30 September 2020; Accepted: 17 October 2020; Published: 20 October 2020

check for updates

Simple Summary: Transcriptomic analysis showed nineteen potential biomarkers in ovarian tissue from females belonged to a rabbit line selected for ovulation rate for 10 generations and the control line. These females differed not only in ovulation rate but also in prenatal survival since similar litter size were observed.

\begin{abstract}
Litter size is an essential trait in rabbit meat production but with low heritability. A selection experiment for ovulation rate has been performed for 10 generations to improve litter size in rabbits. The selected line increased two ova more than the control line but nevertheless a negative correlation was observed with prenatal survival. A transcriptomic study was performed, using microarrays, in ovarian tissue from females belonging to the selected line and the control line. Our results showed 1357 differential expressed genes and nineteen potential biomarkers associated with prenatal mortality, which could explain differences between litter size in rabbits. Cell death was the most relevant process.
\end{abstract}

Keywords: ovulation rate; litter size; transcriptomic analysis; rabbit; ovarian tissue

\section{Introduction}

Ovulation rate and prenatal survival are the main components of litter size in rabbits and pigs. Selection by ovulation rate was proposed, expecting a more efficient improvement in litter size than direct selection. Ovulation rate has been increased with success in the only selection experiment by ovulation rate developed in rabbits. After 10 generations of selection, the selected line (OR line) showed around two ova more than the control line ( $\mathrm{C}$ line). However, litter size was not improved mainly due to a decrease of $12 \%$ in prenatal survival [1-3]. Similar results were found in pigs after selection by ovulation rate [4-7]. Several authors have proposed that a part of the reduction of prenatal survival in females with high ovulation rate could be due to a lower oocyte quality [8,9]. Follicular size, follicular maturity, and specific hormone and protein concentrations in the follicular fluid are related to the oocyte quality, which is required to restart meiosis, fertilization, and early embryo development [10]. Moreover, corpora lutea after ovulation play an important role in the production of progesterone. It is widely known that progesterone is essential to achieve and maintain pregnancy and the timing of the post-ovulatory progesterone rise is critical to the embryonic development and survival. 
Genome-wide expression profiles could be a fundamental strategy to study changes in gene expression after selection based on a trait and to understand the biological processes involved in the expression of selected and related traits. The aim of this paper is to analyze, using microarrays, the transcriptomic profile of ovary tissue from females belonging to the OR line selected by ovulation rate and its control line. Our study can contribute to the understanding of the transcriptome events in ovarian tissue after selection by ovulation rate and offer a theoretical basis to further improve oocyte quality and, therefore, embryo survival and litter size.

\section{Materials and Methods}

\subsection{Ethics Statement}

All experimental procedures were approved by the Universitat Politècnica de València Research Ethics Committee, according to Council Directives 98/58/EC and 2010/63/EU.

\subsection{Animals and Experimental Design}

A total of six nulliparous rabbit females were used to perform the analyses. Three females belonging to the line selected for 10 generations for ovulation rate (OR line), and the other three females belong to the $\mathrm{C}$ line [3]. These three control females were the offspring of a cryopreserved population from generation zero of a OR selection experiment to avoid the effect of the cryopreserved technique.

Females were housed at the farm of the Universitat Politècnica de València in individual cages (flat-deck) with a extractable nest box with isolated plastic, and they were reared under a photoperiod of 16-h light: 8-h dark.

Ovulation is usually induced by coitus in the rabbit. Natural mating was carried out at 20 weeks old, and females were slaughtered by stunning and exsanguination $16 \mathrm{~h}$ later. After slaughter, the complete reproductive tract was removed. Ovary tissue $(30-35 \mathrm{mg})$ from each female were collected in a tube with $200 \mu \mathrm{L}$ of RNAlater (Ambion), frozen at $-196^{\circ} \mathrm{C}$ in liquid nitrogen, and then stored at $-80{ }^{\circ} \mathrm{C}$ until RNA extraction.

\subsection{Total RNA Extraction and Transcriptome Analysis}

Total RNA was isolated directly using Trizol reagent following the manufacturer's instructions (TRIzol, Invitrogen, Thermo-Fisher Scientific). RNA integrity number (RIN) was tested by the 2100 Bioanalyzer (Agilent Technologies, Santa Clara, CA, USA), and RNA concentration and purity were determined using a spectrophotometer (GeneQuant, GE Healthcare, Amersham Biosciences, Missouri, TX, USA). The purity and integrity of total RNA were similar and then comparable $(p$-values $=0.8)$.

GeneChip ${ }^{\circledR}$ Rabbit Gene 1.0 ST Array allows us to analyze 23,282 well-annotated genes with 496,321 different probes with a median of 22 probes per gene. The databases used to design the arrays were Orycun 2.0 and Ensemble (May 2009). Raw data has been deposited in ArrayExpress, a publicly accessible database, with accession number E-MTAB-9406.

CEL files were imported into Partek Genomics Suite v6.6 (Partek, Inc., St. Louis, MO, USA) as CEL files. Raw data were pre-processed, including background correction, normalization, and summarization using robust multi-array average (RMA) analysis and then log2-transformed using Expression Console ${ }^{\mathrm{TM}}$ 1.4.1.46 software from Affymetrix.

One-way ANOVA analysis was performed with Partek Genomics Suite 6.6 software (Partek Inc., St. Louis, MO, USA) to identify differentially expressed genes. A p-value lower than 0.05 was considered as statistically significant. Principal component analysis (PCA) was performed to determine the significant sources of variability in the datasets. PCA reduces the complexity of high-dimensional data and simplifies, identifying expression patterns and sources of variability in a large dataset in a tridimensional fashion. The distance between any pair of points is related to the similarity between two samples in high-dimensional space, in this case, each variable corresponding to a one-dimensional 
space. Later, the genes were ordered according to their expression levels in unsupervised hierarchical clustering. Finally, the differentially expressed genes were imported into Pathway Studio version 10 (Elsevier Inc., Rockville, MD, USA) to identify the main biological processes and pathways with database ResNet v11. An enrichment $p$-value lower than 0.05 was considered as statistically significant.

\section{Results}

\subsection{Transcriptome Profile Analysis in Ovarian Tissue}

The principal component analysis showed the distribution of whole transcriptome in the six ovarian samples recovered $16 \mathrm{~h}$ after mating (Figure 1). Two clustered groups, corresponding to the control and the OR selected females, were observed and the percentage of variability of the three main components was $67.9 \%$. Furthermore, a differential expression analysis was performed, and a total of 1357 differentially expressed genes (DEG) between females from the OR line vs. the control one was found ( $p$-value < 0.05; see Table S1). Of these 1357 DEG, 922 were well-annotated which 529 genes were overexpressed and 393 were underexpressed in the OR line vs. the control line. Significant genes derived from the ANOVA analyses were visualized according to their expression levels in an unsupervised hierarchical clustering (Figure 2). These analyses confirmed that both groups, control and selected by $\mathrm{OR}$, had different transcriptomic pattern.

\section{Principal Component Analysis}

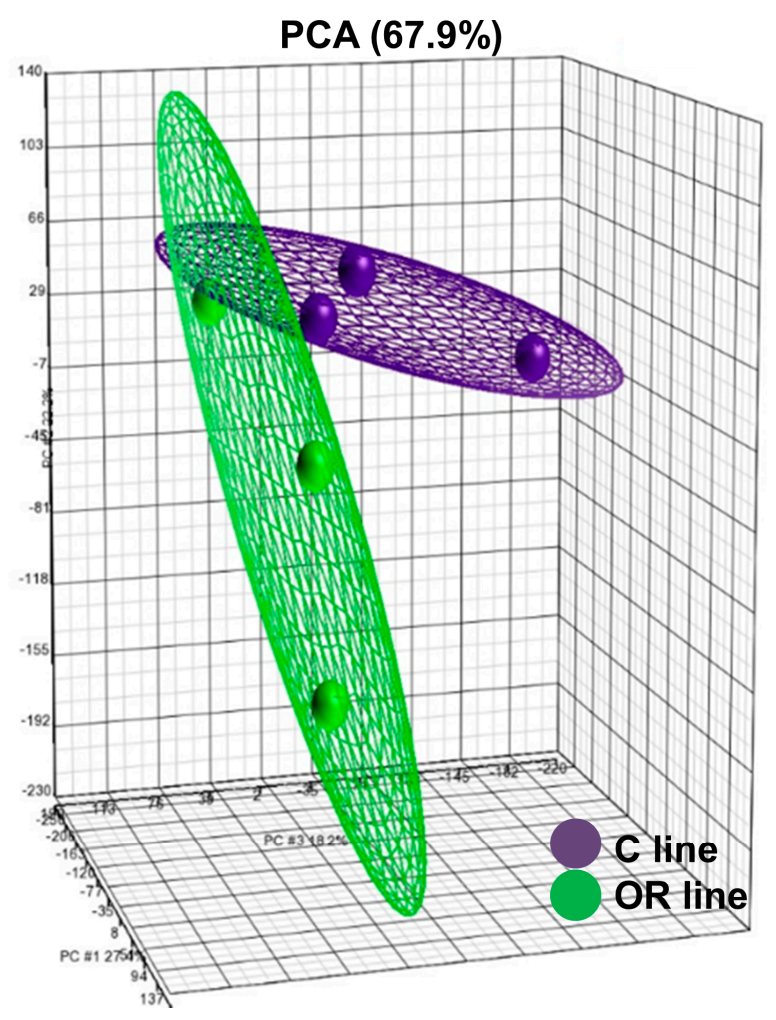

Figure 1. Principal component analysis (PCA) of the whole transcriptome of control line (C line, purple color) and line selected for ovulation rate during 10 generations (OR line, green color) in ovarian tissue. The total percentage of PCA mapping variability is $67.9 \%$. Each data point represents one sample. The ellipsoids highlight the portioning of the different samples. 


\section{Unsupervised Hierarchical clustering}

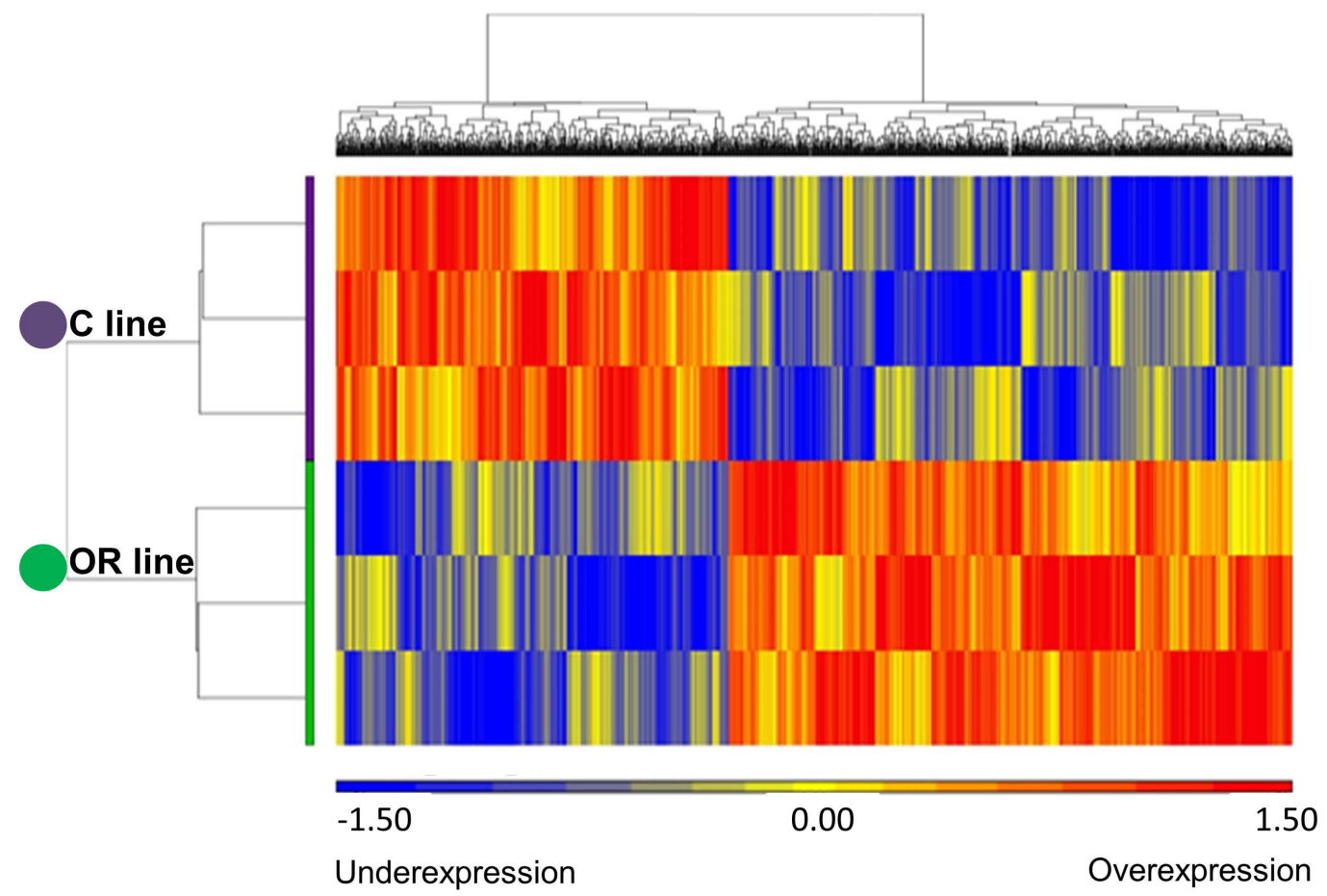

Figure 2. Unsupervised hierarchical clustering of 1357 differentially expressed genes in ovarian tissue. In purple, the control line ( $\mathrm{C}$ line) clustered a completely different manner than the ovulation rate selected line (OR line, in green). Each line represents a sample and each column a gene. Overexpressed genes are represented in red and underexpressed genes in blue.

\subsection{Biological Analysis in Ovarian Tissue}

To understand the biological contribution of the 1357 differentially regulated genes, Pathway Studio (Elsevier) was used. The most representative biological processes filter by enrichment $p$-value are represented in Table 1.

Table 1. The most representative biological processes based on enrichment $p$-values in ovarian tissue.

\begin{tabular}{ccc}
\hline Biological Processes & Number of Genes & Enrichment $\boldsymbol{p}$-Value \\
\hline Multicellular organismal development & 55 & $1.81 \times 10^{-10}$ \\
Cell differentiation & 43 & $8.80 \times 10^{-10}$ \\
Signal transduction & 99 & $1.72 \times 10^{-9}$ \\
Synaptic transmission & 29 & $8.25 \times 10^{-9}$ \\
Apoptotic process & 40 & $3.18 \times 10^{-8}$ \\
Positive regulation of cell proliferation & 29 & $3.50 \times 10^{-7}$ \\
Transmembrane transport & 34 & $6.37 \times 10^{-7}$ \\
Positive regulation of transcription, DNA-templated & 31 & $7.15 \times 10^{-7}$ \\
Positive regulation of I-kappaB kinase-NF-kappaB signaling & 14 & $9.55 \times 10^{-7}$ \\
\hline
\end{tabular}

Moreover, cell process pathways most relevant in the differential gene expression analysis are showed in Table 2. 
Table 2. Relevant cell process pathways based on $p$-values in ovarian tissue.

\begin{tabular}{ccc}
\hline Cell Process Pathways & Number of Genes & Enrichment $p$-Value \\
\hline Apoptosis & 10 & $3.63 \times 10^{-3}$ \\
Melanogenesis & 40 & $4.90 \times 10^{-3}$ \\
Translation Control & 54 & $5.51 \times 10^{-3}$ \\
Actin Cytoskeleton Regulation & 31 & $1.74 \times 10^{-2}$ \\
Thromboxane Receptor-“CREB signaling” & 8 & $2.71 \times 10^{-2}$ \\
Chromosome Condensation & 3 & $3.96 \times 10^{-2}$ \\
Lipoyl-protein complex biosynthesis II & 2 & $4.17 \times 10^{-2}$ \\
Lipoyl-protein complex biosynthesis I & 2 & $4.17 \times 10^{-2}$ \\
Cleavage of Lamina in Apoptosis & 3 & $4.35 \times 10^{-2}$ \\
Histone Phosphorylation & 9 & $4.43 \times 10^{-2}$ \\
\hline
\end{tabular}

We highlighted the apoptosis process because in both Tables 1 and 2, it is a relevant process. For this reason, a custom subnetwork analysis focused on DEG involved in cell death in ovarian tissue was performed (Figure 3). Nineteen genes directly related to this biological process were found; eight overexpressed and 11 underexpressed in the OR line vs. the control line filtered $p$-value $<0.05$ and fold change of $|1.5|$. These nineteen genes represented almost $60 \%$ of the total DEG well-annotated (Table 3).

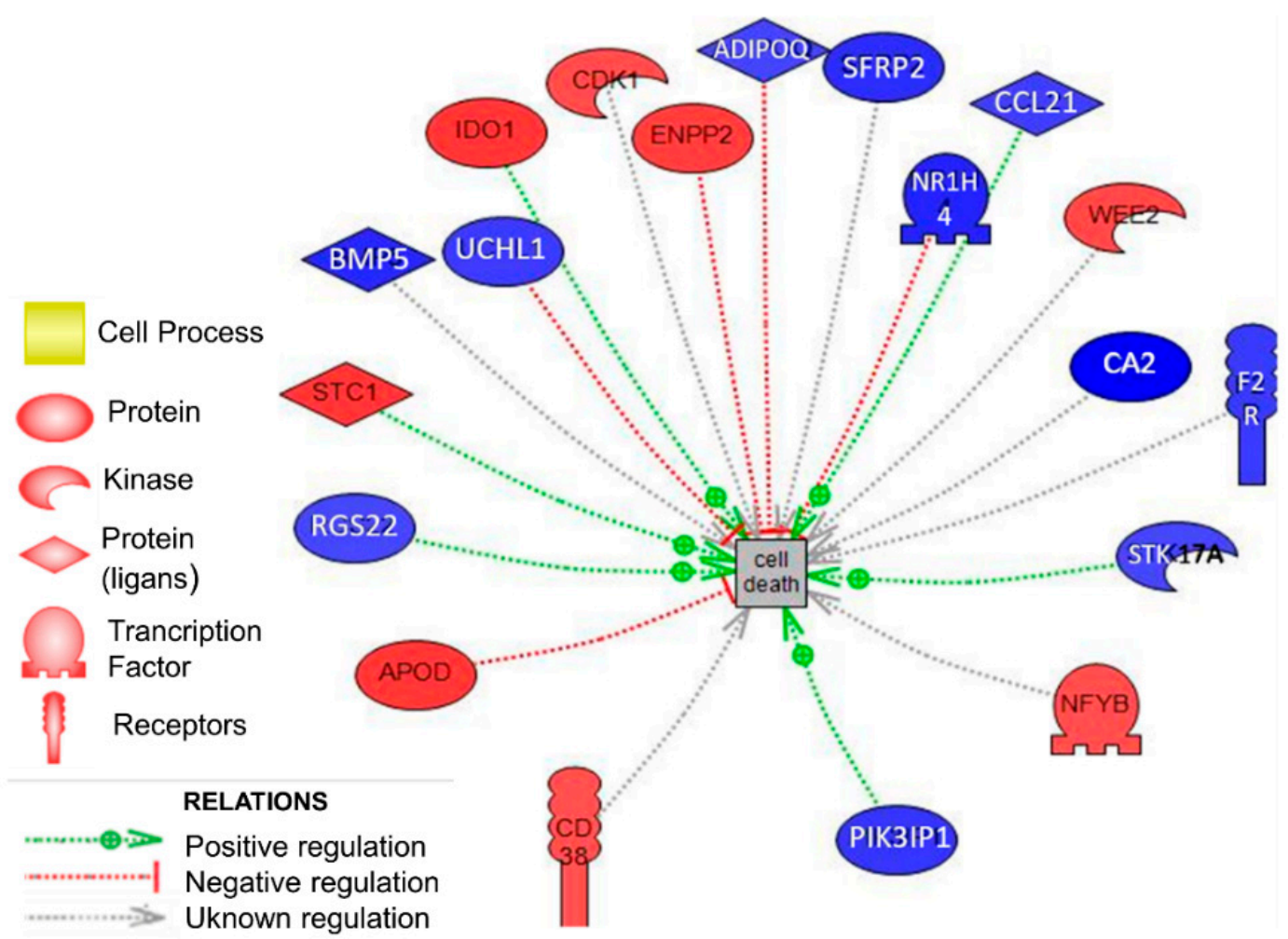

Figure 3. Customized subnetwork analysis focused on nineteen genes involved in cell death in ovarian tissue. Up-regulated (in red) and down-regulated (in blue) genes in the line selected for ovulation rate during 10 generations (OR line) vs. the control line (C line). The dashed line means the regulation relationship. Relations are colored by effect: Red color expressed a negative effect, green color expressed a positive effect, and grey expressed unknown effects. 
Table 3. Nineteen significant differentially expressed genes involved in cell death in ovarian tissue.

\begin{tabular}{cccc}
\hline Gene Symbol & Gene Name & $p$-Value & Fold Change \\
\hline STC1 & Stanniocalcin 1 & $1.11 \times 10^{-2}$ & 1.90 \\
IDO1 & Indoleamine 2.3-dioxygenase 1 & $8.58 \times 10^{-3}$ & 1.89 \\
APOD & Apolipoprotein D & $4.76 \times 10^{-2}$ & 1.88 \\
ENPP2 & Ectonucleotide pyrophosphatase/phosphodiesterase 2 & $2.76 \times 10^{-2}$ & 1.78 \\
WEE2 & WEE1 homolog 2 (S. pombe) & $4.26 \times 10^{-2}$ & 1.62 \\
CDK1 & Cyclin-dependent kinase 1 & $4.09 \times 10^{-2}$ & 1.55 \\
CBFB & Core-binding factor. beta subunit & $4.20 \times 10^{-2}$ & 1.53 \\
CD38 & CD38 molecule & $3.75 \times 10^{-2}$ & 1.52 \\
RGS22 & Regulator of G-protein signaling 22 & $2.69 \times 10^{-2}$ & -1.53 \\
STK17A & Serine/threonine kinase 17a & $1.77 \times 10^{-2}$ & -1.54 \\
ADIPOQ & Adiponectin. C1Q and collagen domain containing & $1.77 \times 10^{-2}$ & -1.57 \\
CCL21 & Chemokine (C-C motif) ligand 21 & $3.56 \times 10^{-2}$ & -1.64 \\
UCHL1 & Ubiquitin carboxyl-terminal esterase L1 & $2.84 \times 10^{-2}$ & -1.69 \\
F2R & Coagulation factor II (thrombin) receptor & $1.80 \times 10^{-2}$ & -1.70 \\
PIK3IP1 & Phosphoinositide-3-kinase interacting protein 1 & $4.65 \times 10^{-2}$ & -1.77 \\
SFRP2 & Secreted frizzled-related protein 2 & $2.20 \times 10^{-2}$ & -1.88 \\
BMP5 & Bone morphogenetic protein 5 & $3.72 \times 10^{-2}$ & -1.97 \\
NR1H4 & Nuclear receptor subfamily 1 group H member 4 & $1.31 \times 10^{-2}$ & -2.03 \\
CA2 & Carbonic anhydrase II & $2.81 \times 10^{-2}$ & -2.75 \\
\hline
\end{tabular}

\section{Discussion}

Litter size is one of the characters with the greatest economic importance in rabbit production [11], and, therefore, maternal lines are selected mainly by litter size [12]. The selection by ovulation rate has been proposed as a way to improve litter size more successfully. In only one selection experiment on ovulation rate performed in rabbits, an increase of approximately two ova were obtained; however, there was no success in improving litter size. This failure to increase litter size despite the increase in the ovulation rate was due to a decrease in prenatal survival (almost $12 \%$ per generation). The increase in prenatal mortality occurred both in the embryonic and fetal periods [1-3]. Laborda and co-workers suggested that a part of the increase in prenatal mortality found in the experiment of selection for ovulation rate could be due to the reduction in oocyte quality since females with high ovulation rate from selected line showed a lower concentration of glutathione [13]. Glutathione is considered as a relevant biochemical marker of the cytoplasmic maturation and consequently of the development and viability of oocytes [14]. In this study, some possible causes of this decrease in prenatal survival were described in terms of transcriptomic results. Microarray-based expression profiling allows characterizing more broadly, causing a specific phenomenon such as a decrease in prenatal survival resulting in no changes in litter size when all the genes are interrogated in a single experiment. It also helps to understand the main biological processes involved in this event.

We found 1357 DEG between the OR line and the control line in ovarian tissue. Most relevant gene expression changes were related to apoptosis and cell death. Apoptosis, a programmed cells death, plays a role on all the stages of oogenesis and even after ovulation [15]. There are several players responsible for oocyte apoptosis such as premature disruption of gap junctions, signal molecules, meiotic competency, and apoptotic factors. In the mentioned review is stated that the generation of reactive oxygen species in oocytes after ovulation regulates anti-apoptotic, proapoptotic, and apoptotic factors. We highlight that one of our biomarkers, Stanniocalcin 1 (STC1) gene was detected in rabbit ovarian tissue for the first time. Our study shows that the overexpression of STC1 could exert a positive regulation in programmed cell death in OR line. STC1 gene encodes a glycoprotein involved in many biological processes such as mineral homeostasis, angiogenesis, and steroidogenesis very relevant in ovarian function [16]. STC1 affects the progesterone production in granulosa cells, and progesterone is essential for embryo survival and development. For this reason, STC1 could have an essential function in corpora lutea. In humans, it is observed that protein A, regulated by STC1, is associated with pregnancy during follicle development [17]. 
Another up-regulated expression gene is Indoleamine 2.3-dioxygenase 1 (IDO)which causes T-cell apoptosis [18-23], anti-proliferative, and proapoptotic effects [24] like Apolipoprotein D (ApoD) [25]. The overexpression of glycoprotein ApoD in the OR line could be modulating immune function [19], stress response, lipid metabolism, ageing, and cell adhesion [26]. The importance of inflammatory response in the ovulatory process is highlighted by the commonalities and similarities between many of the events associated with ovulation and inflammation [27].

The participation of WEE1 homolog 2 (S. pombe) (protein kinase phosphorylates and inhibits family of cyclin-dependent kinase complexes (Cdks)) in cell cycle inhibiting the mitosis [28-32] and apoptosis [33-36] could be one of the reasons about for the failure in litter size in the OR line. This finding confirms that apoptosis is a relevant biological process corroborated in our results.

The presence of nuclear CD38 molecule during different hematopoietic differentiation stages suggests that it may play a role in the control of homeostasis [37] and regulate humoral immune responses [38]. This study shows an overexpression of this gene, and its deficiency could alter adipogenesis and lipogenesis [39], including neurotransmission, cell proliferation, apoptosis, bone remodeling, T lymphocyte signaling, and neutrophil migration [40]. This possible participation of an immune system down could be the consequence of finding chemokines downregulated like Chemokine (C-C motif) ligand 21 (CCL21). We also found that Phosphoinositide-3-kinase interacting protein 1 (PIK3IP1) is downregulated. The dysregulation of the Phosphoinositide-3-kinase (PI3K) pathway is associated with autoimmune disease [41]. Ovulation processes after luteinizing hormone stimulus involves steroids, prostaglandins, chemokines, and cytokines, which are also mediators of inflammatory processes. These mediators activate resident immune cells within the ovary [27]. Granulosa and theca cells of the follicle collaborate with immune cells to produce mediators of ovulation, many of which are also common to inflammatory responses.

A differential underexpressed gene in the OR line compared with the control line observed was Ubiquitin carboxyl-terminal esterase L1 (UCHL1). Its relevant functions are being anti-apoptotic [42,43], a tumor suppressor by inducing G0/G1cell cycle arrest [43], and enhancement of cell proliferation [44]. UCHL1 is highly and specifically expressed in mouse ova and is involved in the polyspermy block [45]. Moreover, UCHL1 is also involved in oocyte development and maturation [46,47]. All mentioned functions could play an important role to explain differences in prenatal survival between the selected and the control line. In our experiment, the proportion of females from the selected line with extremely high OR (more than 20 ova; i.e., twice the standard deviation over the mean) increased from $4 \%$ to $23 \%$ after ten generations of OR selection. Similar to superovulated females, which release oocytes that are less competent (reviewed by Krisher, 2004), females with extremely high ovulation rates from OR line could ovulate oocytes in an early stage of development, which may not be fertilized or may lead to poor-quality embryos that may die either before or after implantation.

Moreover, the angiogenesis process may be blocked by underexpression of regulator of G-protein signaling 22 (RGS22) [48] and coagulation factor II (thrombin) receptor (F2R) $[49,50]$ in the OR line. The non-presence of ovarian angiogenic factors could produce (i.e., vascular epidermal growth factor (VEGF)) damage vascular density necessary during follicular development and the competence of the oocytes [51]. Angiogenesis increased vascular permeability, both vasodilation and vasoconstriction, and edema are essential features of ovulation.

Adiponectin (ADIPOQ) is an adipocyte-derived cytokine present in many reproductive tissues [52]. Their biological functions have expanded from insulin sensitization properties to new effects on inflammation and immunology [52]. Cytokines are inflammatory mediators that stimulate extensive remodeling of the extracellular matrix within the follicle [27]. Others roles are highlighted in fetal growth [53-56], in inhibitory effects on steroidogenesis [57,58], and progesterone secretion by the corpus luteum of the ovary [59]. Furthermore, higher levels of adiponectin are associated with better outcomes in assisted reproductive cycles [52] and success of embryo development [60] in fertile-cows [61]. In the present study the ADIPOQ gene was underexpressed, another author observed that the non-presence could be one of the main causes of infertility and associated with pregnancy-related disorders, 
including polycystic ovarian syndrome [56]. The last candidate, secreted frizzled-related protein 2 (SFRP2), family structurally related to Frizzled (Fz) proteins [62], is found downregulated in the OR line and could activate apoptosis [63] and disturbance in the development of embryogenesis [64]. Bone morphogenetic protein (BMP) [65], nuclear receptor subfamily 1 group H member 4 (NR1H4) [66] and carbonic anhydrase II (CA2) [67] could also contribute to the dysregulation of apoptosis. For this finding, the underexpression of these genes in the OR line vs. the control line could affect the correct development of ovarian tissue in the females belonging to the OR line. Specifically, CA2 was present in the endometrium of the non-pregnant rabbit in a low concentration, with a development of the endometrial activity declined [68].

\section{Conclusions}

The causes of prenatal mortality are a subject of great interest in productive species, such as the rabbit, and in assisted reproduction in humans. The results of this work have highlighted a set of genes that can help to understand better the mechanisms of oocyte maturation and ovulatory process and its relationship with the increase in prenatal mortality in rabbits and other species.

Supplementary Materials: The following are available online at http://www.mdpi.com/2076-2615/10/10/1924/s1, Table S1: 1357 differentially expressed genes between females from the line selected for ovulation rate during 10 generations (OR line) vs. the control line (C line).

Author Contributions: M.S.-G. performed transcriptomic analysis, R.P. and M.A.S. designed and supervised the rabbit experiments, and E.S. directed transcriptomic studies. M.A.S., R.P., M.S.-G., and E.S. contributed to writing paper. All authors have read and agreed to the published version of the manuscript.

Funding: This research was supported by MEC (AGL2014-55921-C2-1-P) and Generalitat Valenciana (Prometeo 2009/125).

Conflicts of Interest: The authors declare no conflict of interest.

\section{References}

1. Laborda, P.; Mocé, M.L.; Blasco, A.; Santacreu, M.A. Selection for ovulation rate in rabbits: Genetic parameters and correlated responses on survival rates1. J. Anim. Sci. 2012, 90, 439-446. [CrossRef] [PubMed]

2. Laborda, P.; Mocé, M.L.; Santacreu, M.A.; Blasco, A. Selection for ovulation rate in rabbits: Genetic parameters, direct response, and correlated response on litter size1. J. Anim. Sci. 2011, 89, 2981-2987. [CrossRef] [PubMed]

3. Laborda, P.; Santacreu, M.A.; Blasco, A.; Mocé, M.L. Selection for ovulation rate in rabbits: Direct and correlated responses estimated with a cryopreserved control population1. J. Anim. Sci. 2012, 90, 3392-3397. [CrossRef] [PubMed]

4. Cunningham, P.J.; England, M.E.; Young, L.D.; Zimmerman, D.R. Selection for ovulation rate in swine: Correlated response in litter size and weight. J. Anim. Sci. 1979, 48, 509-516. [CrossRef] [PubMed]

5. Rosendo, A.; Druet, T.; Gogué, J.; Bidanel, J.P. Direct responses to six generations of selection for ovulation rate or prenatal survival in Large White pigs. J. Anim. Sci. 2007, 85, 356-364. [CrossRef] [PubMed]

6. Johnson, R.K.; Zimmerman, D.R.; Kittok, R.J. Selection for components of reproduction in swine. Livest. Prod. Sci. 1984, 11, 541-558. [CrossRef]

7. Leymaster, K.A.; Christenson, R.K. Direct and correlated responses to selection for ovulation rate or uterine capacity in swine. J. Anim. Sci. 2000, 78 (Suppl. 1), 68.

8. Rodrigues, P.; Limback, D.; McGinnis, L.K.; Plancha, C.E.; Albertini, D.F. Oogenesis: Prospects and challenges for the future. J. Cell. Physiol. 2008, 216, 355-365. [CrossRef]

9. Geisert, R.D.; Schmitt, R.A.M. Early embryonic survival in the pig: Can it be improved? J. Anim. Sci. 2002, 80, E54-E65. [CrossRef]

10. Krisher, R.L. The effect of oocyte quality on development. J. Anim. Sci. 2004, 82 (Suppl. 13), E14-E23. [CrossRef]

11. Cartuche, L.; Pascual, M.; Gómez, E.A.; Blasco, A. Economic weights in rabbit meat production. World Rabbit Sci. 2014, 22, 165. [CrossRef]

12. Khalil, M.H.; Al-Saef, A.M. Methods, criteria, techniques and genetic responses for rabbit selection: A review. In Proceedings of the 9th World Rabbit Congress, Verona, Italy, 10-13 June 2008; pp. 1-22. 
13. Laborda, P.; Santacreu, M.A.; García, E.; Mocé, E.; Mocé, M.L. Oocyte glutathione concentration in a rabbit line selected for ovulation rate. In Proceedings of the 9th World Rabbit Congress, Verona, Italy, 10-13 June 2008; pp. 375-379.

14. Zuelke, K.A.; Jeffay, S.C.; Zucker, R.M.; Perreault, S.D. Glutathione (GSH) concentrations vary with the cell cycle in maturing hamster oocytes, zygotes, and pre-implantation stage embryos. Mol. Reprod. Dev. 2003, 64, 106-112. [CrossRef] [PubMed]

15. Tiwari, M.; Prasad, S.; Tripathi, A.; Pandey, A.N.; Ali, I.; Singh, A.K.; Shrivastav, T.G.; Chaube, S.K. Apoptosis in mammalian oocytes: A review. Apoptosis 2015, 20, 1019-1025. [CrossRef]

16. Gerritsen, M.E.; Wagner, G.F. Stanniocalcin: No Longer Just a Fish Tale. Vitam. Hormon. 2005, 70, $105-135$. [CrossRef]

17. Jepsen, M.R.; Kløverpris, S.; Bøtkjær, J.A.; Wissing, M.L.; Andersen, C.Y.; Oxvig, C. The proteolytic activity of pregnancy-associated plasma protein-A is potentially regulated by stanniocalcin-1 and -2 during human ovarian follicle development. Hum. Reprod. 2016, 31, 866-874. [CrossRef] [PubMed]

18. Darcy, C.J.; Davis, J.S.; Woodberry, T.; McNeil, Y.R.; Stephens, D.P.; Yeo, T.W.; Anstey, N.M. An observational cohort study of the kynurenine to tryptophan ratio in sepsis: Association with impaired immune and microvascular function. PLOS ONE 2011, 6. [CrossRef]

19. Wirthgen, E.; Tuchscherer, M.; Otten, W.; Domanska, G.; Wollenhaupt, K.; Tuchscherer, A.; Kanitz, E. Activation of indoleamine 2,3-dioxygenase by LPS in a porcine model. Innate Immun. 2014, 20, 30-39. [CrossRef]

20. Mohib, K.; Guan, Q.; Diao, H.; Du, C.; Jevnikar, A.M. Proapoptotic activity of indoleamine 2,3-dioxygenase expressed in renal tubular epithelial cells. Am. J. Physiol. Ren. Physiol. 2007, 293. [CrossRef]

21. Fallarino, F.; Grohmann, U.; Vacca, C.; Bianchi, R.; Orabona, C.; Spreca, A.; Fioretti, M.C.; Puccetti, P. T cell apoptosis by tryptophan catabolism. Cell Death Differ. 2002, 9, 1069-1077. [CrossRef]

22. Wang, Q.; Zhang, M.; Ding, Y.; Wang, Q.; Zhang, W.; Song, P.; Zou, M.H. Activation of NAD(P)H oxidase by Tryptophan-derived 3-Hydroxykynurenine accelerates endothelial apoptosis and dysfunction in Vivo. Circ. Res. 2014, 114, 480-492. [CrossRef]

23. Fangxuan, L.; Rupeng, Z.; Shixia, L.; Juntian, L. IDO1: An important immunotherapy target in cancer treatment. Int. Immunopharmacol. 2017, 47, 70-77.

24. Hill, M.; Pereira, V.; Chauveau, C.; Zagani, R.; Remy, S.; Tesson, L.; Mazal, D.; Ubillos, L.; Brion, R.; Ashgar, K.; et al. Heme oxygenase-1 inhibits rat and human breast cancer cell proliferation: Mutual cross inhibition with indoleamine 2,3-dioxygenase. FASEB J. 2005, 19, 1957-1968. [CrossRef] [PubMed]

25. Lieuallen, K. Cystatin B-deficient mice have increased expression of apoptosis and glial activation genes. Hum. Mol. Genet. 2001, 10, 1867-1871. [CrossRef] [PubMed]

26. Pajaniappan, M.; Glober, N.K.; Kennard, S.; Liu, H.; Zhao, N.; Lilly, B. Endothelial cells downregulate apolipoprotein D expression in mural cells through paracrine secretion and Notch signaling. Am. J. Physiol. Heart Circ. Physiol. 2011, 301. [CrossRef]

27. Duffy, D.M.; Ko, C.; Jo, M.; Brannstrom, M.; Curry, T.E. Ovulation: Parallels With Inflammatory Processes. Endocr. Rev. 2019, 40, 369-416. [CrossRef] [PubMed]

28. Liu, C.; Liu, Y.; Liu, Y.; Wu, D.; Luan, Z.; Wang, E.; Yu, B. Ser 15 of WEE1B is a potential PKA phosphorylation target in G2/M transition in one-cell stage mouse embryos. Mol. Med. Rep. 2013, 7, 1929-1937. [CrossRef]

29. Seung, J.H.; Chen, R.; Paronetto, M.P.; Conti, M. Wee1B is an oocyte-specific kinase involved in the control of meiotic arrest in the mouse. Curr. Biol. 2005, 15, 1670-1676. [CrossRef]

30. Nakanishi, M.; Ando, H.; Watanabe, N.; Kitamura, K.; Ito, K.; Okayama, H.; Miyamoto, T.; Agui, T.; Sasaki, M. Identification and characterization of human Wee1B, a new member of the Wee1 family of Cdk-inhibitory kinases. Genes Cells 2000, 5, 839-847. [CrossRef]

31. Oh, J.S.; Susor, A.; Conti, M. Protein tyrosine kinase wee1B is essential for metaphase II exit in mouse oocytes. Science 2011, 332, 462-465. [CrossRef]

32. Castedo, M.; Perfettini, J.L.; Roumier, T.; Kroemer, G. Cyclin-dependent kinase-1: Linking apoptosis to cell cycleand mitotic catastrophe. Cell Death Differ. 2002, 9, 1287-1293. [CrossRef]

33. Golsteyn, R.M. Cdk1 and Cdk2 complexes (cyclin dependent kinases) in apoptosis: A role beyond the cell cycle. Cancer Lett. 2005, 217, 129-138. [CrossRef]

34. Gu, L.; Zheng, H.; Murray, S.A.; Ying, H.; Jim Xiao, Z.X. Deregulation of Cdc2 kinase induces caspase-3 activation and apoptosis. Biochem. Biophys. Res. Commun. 2003, 302, 384-391. [CrossRef] 
35. Sandal, T.; Stapnes, C.; Kleivdal, H.; Hedin, L.; Døskeland, S.O. A novel, extraneuronal role for cyclin-dependent protein kinase 5 (CDK5): Modulation of cAMP-induced apoptosis in rat leukemia cells. J. Biol. Chem. 2002, 277, 20783-20793. [CrossRef] [PubMed]

36. Oh, J.S.; Susor, A.; Schindler, K.; Schultz, R.M.; Conti, M. Cdc25A activity is required for the metaphase II arrest in mouse oocytes. J. Cell Sci. 2013, 126, 1081-1085. [CrossRef]

37. Orciani, M.; Trubiani, O.; Guarnieri, S.; Ferrero, E.; Di Primio, R. CD38 is constitutively expressed in the nucleus of human hematopoietic cells. J. Cell. Biochem. 2008, 105, 905-912. [CrossRef]

38. Partidá-Sánchez, S.; Rivero-Nava, L.; Shi, G.; Lund, F.E. CD38: An ecto-enzyme at the crossroads of innate and adaptive immune responses. In Crossroads between Innate and Adaptive Immunity. Advances in Experimental Medicine and Biology; Katsikis, P.D., Schoenberger, S.P., Pulendran, B., Eds.; Springer: Boston, MA, USA, 2007; Volume 590, pp. 171-183. [CrossRef]

39. Wang, L.F.; Miao, L.J.; Wang, X.N.; Huang, C.C.; Qian, Y.S.; Huang, X.; Wang, X.L.; Jin, W.Z.; Ji, G.J.; Fu, M.; et al. CD38 deficiency suppresses adipogenesis and lipogenesis in adipose tissues through activating Sirt1/PPAR $\gamma$ signaling pathway. J. Cell. Mol. Med. 2018, 22, 101-110. [CrossRef] [PubMed]

40. Sun, L.; Iqbal, J.; Zaidi, S.; Zhu, L.L.; Zhang, X.; Peng, Y.; Moonga, B.S.; Zaidi, M. Structure and functional regulation of the CD38 promoter. Biochem. Biophys. Res. Commun. 2006, 341, 804-809. [CrossRef] [PubMed]

41. Uche, U.U.; Piccirillo, A.R.; Kataoka, S.; Grebinoski, S.J.; D'Cruz, L.M.; Kane, L.P. PIK3IP1/TrIP restricts activation of T cells through inhibition of PI3K/Akt. J. Exp. Med. 2018, 215, 3165-3179. [CrossRef]

42. Chu, K.Y.; Li, H.; Wada, K.; Johnson, J.D. Ubiquitin C-terminal hydrolase L1 is required for pancreatic beta cell survival and function in lipotoxic conditions. Diabetologia 2012, 55, 128-140. [CrossRef]

43. Xiang, T.; Li, L.; Yin, X.; Yuan, C.; Tan, C.; Su, X.; Xiong, L.; Putti, T.C.; Oberst, M.; Kelly, K.; et al. The ubiquitin peptidase UCHL1 induces G0/G1 cell cycle arrest and apoptosis through stabilizing p53 and is frequently silenced in breast cancer. PLOS ONE 2012, 7. [CrossRef]

44. Kabuta, T.; Mitsui, T.; Takahashi, M.; Fujiwara, Y.; Kabuta, C.; Konya, C.; Tsuchiya, Y.; Hatanaka, Y.; Uchida, K.; Hohjoh, H.; et al. Ubiquitin C-terminal hydrolase L1 (UCH-L1) acts as a novel potentiator of cyclin-dependent kinases to enhance cell proliferation independently of its hydrolase activity. J. Biol. Chem. 2013, 288, 12615-12626. [CrossRef] [PubMed]

45. Koyanagi, S.; Hamasaki, H.; Sekiguchi, S.; Hara, K.; Ishii, Y.; Kyuwa, S.; Yoshikawa, Y. Effects of ubiquitin C-terminal hydrolase L1 deficiency on mouse ova. Reproduction 2012, 143, 271-279. [CrossRef] [PubMed]

46. Susor, A.; Liskova, L.; Toralova, T.; Pavlok, A.; Pivonkova, K.; Karabinova, P.; Lopatarova, M.; Sutovsky, P.; Kubelka, M. Role of Ubiquitin C-Terminal Hydrolase-L1 in Antipolyspermy Defense of Mammalian Oocytes1. Biol. Reprod. 2010, 82, 1151-1161. [CrossRef]

47. Yao, Y.W.; Shi, Y.; Jia, Z.F.; Jiang, Y.H.; Gu, Z.; Wang, J.; Aljofan, M.; Sun, Z.G. PTOV1 is associated with $\mathrm{UCH}-\mathrm{L} 1$ and in response to estrogen stimuli during the mouse oocyte development. Histochem. Cell Biol. 2011, 136, 205-215. [CrossRef]

48. Boelte, K.C.; Gordy, L.E.; Joyce, S.; Thompson, M.A.; Yang, L.; Lin, P.C. Rgs2 mediates pro-angiogenic function of Myeloid derived suppressor cells in the tumor microenvironment via upregulation of MCP-1. PLoS ONE 2011, 6. [CrossRef]

49. Siller-Matula, J.M.; Schwameis, M.; Blann, A.; Mannhalter, C.; Jilma, B. Thrombin as a multi-functional enzyme: Focus on in vitro and in vivo effects. Thromb. Haemost. 2011, 106, 1020-1033. [CrossRef]

50. Zania, P.; Kritikou, S.; Flordellis, C.S.; Maragoudakis, M.E.; Tsopanoglou, N.E. Blockade of angiogenesis by small molecule antagonists to protease-activated receptor-1: Association with endothelial cell growth suppression and induction of apoptosis. J. Pharmacol. Exp. Ther. 2006, 318, 246-254. [CrossRef]

51. Van Blerkom, J.; Antczak, M.; Schrader, R. The developmental potential of the human oocyte is related to the dissolved oxygen content of follicular fluid: Association with vascular endothelial growth factor levels and perifollicular blood flow characteristics. Hum. Reprod. 1997, 12, 1047-1055. [CrossRef]

52. Michalakis, K.G.; Segars, J.H. The role of adiponectin in reproduction: From polycystic ovary syndrome to assisted reproduction. Fertil. Steril. 2010, 94, 1949-1957. [CrossRef] [PubMed]

53. Čikoš, Š. Adiponectin and Its Receptors in Preimplantation Embryo Development. Vitam. Horm. 2012, 90, 211-238. [CrossRef]

54. Richards, J.S.; Liu, Z.; Kawai, T.; Tabata, K.; Watanabe, H.; Suresh, D.; Kuo, F.T.; Pisarska, M.D.; Shimada, M. Adiponectin and its receptors modulate granulosa cell and cumulus cell functions, fertility, and early embryo development in the mouse and human. Fertil. Steril. 2012, 98. [CrossRef] 
55. Monget, P.; Chabrolle, C.; Dupont, J. Tissu adipeux, nutrition et reproduction: Quel lien? [Adipose tissue, nutrition and reproduction: What is the link?]. Bull. Acad. Natl. Med. 2008, 192, 637-647. [PubMed]

56. Dos Santos, E.; Pecquery, R.; de Mazancourt, P.; Dieudonné, M.N. Adiponectin and Reproduction. In Vitamins \& Hormones; Academic Press Inc.: Cambridge, MA, USA, 2012; Volume 90, pp. 187-209. [CrossRef]

57. Lagaly, D.V.; Aad, P.Y.; Grado-Ahuir, J.A.; Hulsey, L.B.; Spicer, L.J. Role of adiponectin in regulating ovarian theca and granulosa cell function. Mol. Cell. Endocrinol. 2008, 284, 38-45. [CrossRef] [PubMed]

58. Palin, M.F.; Bordignon, V.V.; Murphy, B.D. Adiponectin and the Control of Female Reproductive Functions. Vitam. Horm. 2012, 90, 239-287. [CrossRef]

59. Wickham, E.P.; Tao, T.; Nestler, J.E.; McGee, E.A. Activation of the LH receptor up regulates the type 2 adiponectin receptor in human granulosa cells. J. Assist. Reprod. Genet. 2013, 30, 963-968. [CrossRef]

60. Chappaz, E.; Albornoz, M.S.; Campos, D.; Che, L.; Palin, M.F.; Murphy, B.D.; Bordignon, V. Adiponectin enhances in vitro development of swine embryos. Domest. Anim. Endocrinol. 2008, 35, 198-207. [CrossRef]

61. Elis, S.; Coyral-Castel, S.; Freret, S.; Cognié, J.; Desmarchais, A.; Fatet, A.; Rame, C.; Briant, E.; Maillard, V.; Dupont, J. Expression of adipokine and lipid metabolism genes in adipose tissue of dairy cows differing in a female fertility quantitative trait locus. J. Dairy Sci. 2013, 96, 7591-7602. [CrossRef]

62. Bovolenta, P.; Esteve, P.; Ruiz, J.M.; Cisneros, E.; Lopez-Rios, J. Beyond Wnt inhibition: New functions of secreted Frizzled-related proteins in development and disease. J. Cell Sci. 2008, 121, 737-746. [CrossRef]

63. Arslanoglu, S.; Bertino, E.; Tonetto, P.; De Nisi, G.; Ambruzzi, A.M.; Biasini, A.; Profeti, C.; Spreghini, M.R.; Moro, G.E.; Moro, G.E. Guidelines for the establishment and operation of a donor human milk bank. J. Matern. Neonatal Med. 2010, 23, 1-20. [CrossRef]

64. Lin, C.T.; Lin, Y.T.; Kuo, T.F. Investigation of mRNA Expression for Secreted Frizzled-Related Protein 2 (sFRP2) in Chick Embryos. J. Reprod. Dev. 2007, 53, 801-810. [CrossRef]

65. Jaatinen, R.; Bondestam, J.; Raivio, T.; Hildén, K.; Dunkel, L.; Groome, N.; Ritvos, O. Activation of the Bone Morphogenetic Protein Signaling Pathway Induces Inhibin $\beta$ B -Subunit mRNA and Secreted Inhibin B Levels in Cultured Human Granulosa-Luteal Cells. J. Clin. Endocrinol. Metab. 2002, 87, 1254-1261. [CrossRef] [PubMed]

66. De Gottardi, A.; Dumonceau, J.M.; Bruttin, F.; Vonlaufen, A.; Morard, I.; Spahr, L.; Rubbia-Brandt, L.; Frossard, J.L.; Dinjens, W.N.M.; Rabinovitch, P.S.; et al. Expression of the bile acid receptor FXR in Barrett's esophagus and enhancement of apoptosis by guggulsterone in vitro. Mol. Cancer 2006, 5. [CrossRef]

67. Claudy, A.L. La vascularisation cutanée. Angiogénèse. Structure et fonction des cellules endothéliales. [Cutaneous vascularization. Angiogenesis. Structure and function of endothelial cells]. Ann. Dermatol. Venereol. 1991, 118, 61-68. [PubMed]

68. Lutwak-mann, C. Carbonic anhydrase in the female reproductive tract; occurrence, distribution and hormonal dependence. J. Endocrinol. 1955, 13, 26-38. [CrossRef] [PubMed]

Publisher's Note: MDPI stays neutral with regard to jurisdictional claims in published maps and institutional affiliations.

(C) 2020 by the authors. Licensee MDPI, Basel, Switzerland. This article is an open access article distributed under the terms and conditions of the Creative Commons Attribution (CC BY) license (http://creativecommons.org/licenses/by/4.0/). 